\title{
Power Electronics and Drive Systems
}

Novel AZSPWM Algorithms based VCIMD for Reduced CMV Variations

Kola Satya Narayana, A. Kailasa Rao, K. Satyanarayana

Single-Phase Single-Stage PV-Grid System Using VSI Based on Simple Control Circuit

$9-16$

Slamet Riyadi

V2G Technology to Design a Smart Active Filter for Solar Power System

F. R. Islam, H. R. Pota

A high regulated low ripple DC power supply based on LC filter \& IGBT Ayan Mitra, Abhisek Roy

$30-40$

Induction Motor Speed Control Using Indirect Z-source Matrix Converter with PSO-PI Controller

under Various Break Conditions

Majid Salim, Mohammad Sarvi

Soft Computing Module of High Step-Up DC-DC Converter for PV Module using Simulink Environment

K. Vinoth Kumar, S.Suresh Kumar, S.Daison Stallon

A Multilevel Inverter Based on SVPWM Technique for Photovoltaic Application.

Shantanu Chatterjee

Power Electronics Converters for Variable Speed Pump Storage

Othman Hassan Abdalla, Minxiao Han

Design and Economic Study for Use the Photovoltaic Systems for Electricity Supply in Isfahan Museum

Park

Hossein Shahinzadeh, Mohammad Moien Najaf Abadi, Mohammad Hajahmadi, Ali Paknejad

Low Voltage Ride-Through of Doubly Fed Induction Machine using Direct Torque Control Strategy

G. Venu Madhav, Y. P. Obulesu

Comparative Analysis of Different PWM Techniques to Reduce the Common Mode Voltage in Three-

Level Neutral-Point-Clamped Inverters for Variable Speed Induction Drives

Bharati Raja, S. Raghu

Design of Feedback Controller for Boost Converter Using Optimization Technique

Sesha Giri Rao Galam, S. Raghu, N. Rajasekaran

Responsibility of the contents rests upon the authors and not upon the publisher or editor.

\begin{tabular}{|c|c|c|c|c|c|}
\hline IJPEDS & Vol. 3 & No. 1 & pp. 1-128 & $\begin{array}{c}\text { Malacca, } \\
\text { March } 2013\end{array}$ & ISSN 2088-8694 \\
\hline
\end{tabular}




\section{ABSTRACT}

Integrating electric energy generated by PV with utilities has been developed. Some of these using two-stage converters and the others using single stage converters. For systems with two-stage converters, the first stage converter acts as a MPPT to maximize power generated by PV and the second stage is used as an interface to the utilities. In the single-stage system, an inverter is used for both function. In this paper, PV-Grid System using a single-stage Voltage Source Inverter is proposed. The simple control circuit to make PV generate maximum power and keeping power equilibrium between PV and inverter output power is used. To verify the analysis, simulations are done. 